\title{
Volatility Analysis of Stock Returns for Fifteen Listed Banks in Chittagong Stock Exchange
}

\author{
Md Rokonuzzaman ${ }^{1}$, Mohammad Akram Hossen ${ }^{2}$ \\ ${ }^{1}$ Department of Statistics, University of Chittagong, Chittagong, Bangladesh \\ ${ }^{2}$ Bangladesh University of Business and Technology, Dhaka, Bangladesh \\ Correspondence: Md Rokonuzzaman, Department of Statistics, University of Chittagong, Chittagong, \\ Bangladesh.
}

Received: May 15, 2018

doi:10.5539/ibr.v11n9p129
Accepted: August 25, 2018

Online Published: August 27, 2018

URL: https://doi.org/10.5539/ibr.v11n9p129

\begin{abstract}
The aim of the study is to analyze and prediction of return for 15 popular banks in Chittagong Stock Exchange. The economic development of a country depends largely on the effective performance of stock market. In this study, secondary data from the CSE, Bangladesh with a sample period 1st January 2009 to 27th December 2015 for selected 15 banks, listed in Chittagong Stock Exchange. Descriptive statistics, important graphs, statistical tests, fitted dynamic regression models with $\mathrm{ARCH}$ effect are used to complete the analysis. It is found that for all banks, the return occurs high with a high risk and risk is low for the companies with small amount of return. The daily log returns for all companies are almost normally distributed. Checking the stationarity of the log returns data getting from all banks in both graphical and statistical unit root method, time series data are found to be stationary. In the dynamic regression model the $\log$ return $\mathrm{Y}_{\mathrm{t}}$ is considered as dependent variable and the log daily average $X_{t}$ is considered as independent variable. The average VIF for the returns of all banks are found less than 10, indicate not severity of multicollinearity and $\Delta Y_{t}, \Delta^{2} Y_{t}, \Delta X_{t}, \Delta^{2} X_{t}$ can be used as the explanatory variables in the model where $\Delta$ indicates the difference operator. Lagrange multiplier (LM) test based on the residuals of the regression model is significant for all the banks implies that the data have the conditional heteroscadisticity in the behavior of their residuals. The line diagrams conferred the complete randomness in Parkinson's monthly volatility for every company. The log return of six out of 15 banks have significant ARCH effect with 2 period lags and rest of the banks, the log returns have significant ARCH effect with 1 period lag.

The regression coefficients of $Y_{t-1}, Y_{t-2}$ and $X_{t-2}$ have the negative effects on $Y_{t}$ and the other coefficients have both positive and negative effect. A modified ARDL (2,2) model is proposed and 1-step ahead forecasted model for different banks are recommended.

One can try to estimate the confidence interval for the parameters used in modified model in his/her advanced research. Moreover, the other dynamic models such as GARCH, TGARCH, PARCH, EGARCH model and different dynamic panel data models such as Areonalo bond could be try to predict the data. Moreover, the other multivariate analysis such as canonical correlation analysis, factor analysis, cluster analysis and discriminant analysis can be done for further research on these data.
\end{abstract}

Keywords: volatility, arch model, parkinson's volatility, stationary, unit root test

\section{Introduction}

A stock is a certificate that gives the holder part-ownership of a company. In order to raise money, a company releases shares that the public can buy. Each share represents a small percentage of ownership in that company. A stock market, equity market or share market is the aggregation of buyers and seller of stocks or shares of companies. In Bangladesh there are two stock exchanges with automation system of trading shares and securities. 
The purpose of a stock exchange is to facilitate the exchange of securities between buyers and sellers, thus providing a marketplace. It is impossible to predict with any certainty how the overall stock market will behave. The stock market can be very volatile, and in a bad day one could see the loss of a significant part of his investment. However, there have always been alternatives such as brokers trying to bring parties together to trade outside the exchange. Stock market is considered to be a barometer of the Economy. The economic development of a country depends largely on the effective performance of stock market. Stock markets play an essential role in growing industries that ultimately affect the economy through transferring available funds from units that have excess funds to those who are suffering from funds deficit (Naik and Padhi 2012).

A stock market crash is often happened for various economic factors, a reason is also due to panic and investing public's loss of confidence. Often, stock market crashes end speculative economic bubbles defined as a sharp dip in share prices of stocks listed on the stock exchanges. There have been famous stock market crashes that have ended in the loss of billions of dollars and wealth destruction on a massive scale. There have been a number of famous stock market crashes like the Wall Street Crash of 1929, the stock market crash of 1973-4, the Black Monday of 1987, the Dot-com bubble of 2000, and the Stock Market Crash of 2008. In Bangladesh there were two stock market crashes i.e., the DSE(DHAKA Stock exchange) crash of 1996, the DSE \& CSE crash of 2010.

Bangladesh capital market is one of the smallest in Asia but within the south Asian region, it is the third largest one. It has only two automated stock exchange Namely Dhaka Stock Exchange (DSE), Chittagong stock exchange (CSE). The stock market of Bangladesh has been experiencing uneven flow of investors across years since its inception. The reverse is also found to be true in the context of Bangladesh. In Bangladesh, there are almost 3.50 million stock market investors, but the number of active investors is 0.16 million. However, the number of active investors may increase or decrease depending on stock market performance of the country.

Chittagong Stock Exchange (CSE) opening Bangladesh Government is the second stock exchange of the country which began its journey in 10th October of 1995 from Chittagong City through the cry-out trading system. It is promise to create an effective, efficient and transparent market atmosphere of international standard to save and invest in Bangladesh in order to raise fund and accelerate industrial growth for overall benefit of the economy.

The main objective of this study is to investigate the dynamics of the time varying volatility for the selected 15 renowned banks of CSE 50 index over the sample period. Another objective of this study is to evaluate stock market performance of the Chittagong Stock Exchange. As capital market volatility is effectively depicted with the help of ARCH model with ARDL $(p, q)$ have been performed so as to produce the evidence of time varying volatility which shows clustering, high persistence and predictability and responds symmetrically for positive and negative shocks.

However, the specific objectives of this thesis are to evaluate the performance of selected bank, to build an appropriate volatility model of daily log return for a bank and to forecast or predict stock market return which helps in investment.

\section{Literature Review}

Numerous financial economists have employed conditional heteroscedasticity models to describe the volatility of the world's developed stock markets. The conditional volatility of stock returns in the U.S. has been examined, most notably by French (1987) and Baillie (1990). Masulis (1995) studies the volatility of the International Stock Exchange of London using generalized ARCH model. Beer (2006) find evidence of asymmetric effects on Shanghai A-share and B-share indices within TGARCH $(1,1)$ model. D.D.Tewari (2013) have studied existence and the nature of the volatility clustering phenomenon in the Johannesburg Stock Exchange (JSE) considering GARCH-type models. Study results revealed that an asymmetric effect of positive and negative shocks on conditional volatility could not be identified. Suliman Zakaria (2012) have studied Stock market volatility in two African exchanges, Khartoum Stock Exchange, KSE (from Sudan) and Cairo and Alexandria Stock Exchange by employing different univariate specifications of the Generalized Autoregressive Conditional Heteroscedasticity model. Zi-Yi (2017) have done a research and used GARCH (p, q) model in order to find the risk-return relationship. They found the negative relationship between risk and return and statistically significant, which indicates that the portfolio theory does not exist in DSE, very contradictory to us. The studies such as, Hassan (2002 \& 2004), Ainul (2005), Kader (2005), Mobarek (2008), Uddin (2009) do not support the weak form of efficiency of Bangladesh's Dhaka Stock Exchange market. There have been also a very few studies like; Hassan (2008), Uddin (2008) support the existence of weak form efficiency of Bangladesh stock market. According to the knowledge of the authors a very few number of researchers have done work in order to find the relationship between risk and return over the past decades of DSE using the GARCH model. Chowdhury (2001) have studied the relationship between the predicted volatility of DSE returns and that of selected macroeconomic variables of 
Bangladesh economy. They have calculated volatility from errors after using an autoregressive and seasonality adjusted forecasting model. The volatility series derived from such process has some limitations, which have been corrected in Generalized Conditional Auto Regressive Heteroscedasticity (GCARH) models developed by (Bollerslev, 1986). A large number of researcher's used ARCH and GARCH in capturing the dynamic characteristics of stock market return across the countries, such as Islam (2013a), Elsheikh (2011), Engle (1987), Bae (2007), Bucevska (2012), Dima Alberga (2008), Ajab Al Freedi (2012) and many more. Md. Ariful Islam (2014) has studied Stock market volatility comparison between Dhaka stock exchange and Chittagong stock exchange considering Standard deviation, coefficient of Variation, F-test. Study results revealed that stock price at CSE is more volatile than DSE. Even the stock price of leading companies (top 20 and 30 companies of DSE and CSE) also varies from DSE to CSE and the volatility is much high than CSE30 of DSE20.

\section{Data and Methodology}

In this study, the daily log returns based on the daily total turnover values of 15 renowned banks of CSE 50 index have been analyzed. The required secondary data are collected for the sample period 1st January 2009 to 27th December 2015 from the CSE, Bangladesh. Most financial studies involve returns, instead of prices of assets. Campbell (1997) give two main reasons for using returns. First, for average investors, return of an asset is a complete and scale-free summary of the investment opportunity. Second, return series are easier to handle than price series because the former have more attractive statistical properties. The natural logarithm of the simple gross return of an asset is called the continuously compounded return or log return:

$$
\ln r_{t}=\ln \left(1+R_{t}\right)=\ln \frac{P_{t}}{P_{t-1}}=\ln P_{t}-\ln P_{t-1} ; r_{t}=1+R_{t}
$$

Stationarity is an important issue to fit any model in time series analysis. A popular statistical approach is Augmented Dickey Fuller statistic to test whether the log return lnrt of an asset follows a random walk or a random walk with drift. i.e. the data is stationary or not. This is also the well-known unit-root testing problem by Dickey (1979).

Multicollinearity is a remarkable issue to fit a regression model. Here VIF is used for detecting of multicollinearity among the explanatory variables used in a regression model.

There are several measures of volatility such as intra-day high-low volatility and inter-day close price or open price volatility. Among these measures Parkinson (1980) extreme value estimator based on intra-day high and low price of an asset is more efficient. The Parkinson's volatility is denoted by $\sigma$ and defined as

$$
\sigma=k \sqrt{\Sigma \ln \frac{\left(H_{t} / L_{t}\right)^{2}}{n}}
$$

Where, $\mathrm{H}_{\mathrm{t}}=$ High price of an asset at time $\mathrm{t}, \quad \mathrm{L}_{\mathrm{t}}=$ Low price of an asset at time $\mathrm{t}$

$$
\mathrm{n}=\text { No of days used in calculation, } \quad k=0.601
$$

Here ARCH model is employed for analyzing and prediction of data.

\section{Result and Discussions}

In this study, 15 popular banks of CSE 50 index are considered for this analysis. The month wise average of that for different banks are presented in the Table 1. In month wise comparison AB bank and EXIM bank have the value of average gross return ranges from1.13 to1.56 i.e., consistent. Average gross return of AL ARAFAH bank's lies between 1.36 and 1.75 for all month except 2.02 in August, 3.22 in November and 2.20 in December, are not stable. The averages of CITY bank are almost consistent which lies between 1.30 and 1.55 except 2.04 in September. DHAKA bank's average gross returns are not consistent having extreme value in January, March, May, October, November. IFIC bank's average value lies between 1.38 and 1.65 except 2.12 in January, 2.36 in June, 2.39 in September, 2.01 in December i.e., inconsistent. The average value of ISLAMI bank are almost stable by ranging from 1.27 to 1.63 without 2.22 in June. NATIONAL bank and NCC bank have the consistent gross return ranging from 1.11 to 1.59 and from 1.18 to 1.38 respectively. ONE bank's averages lies between 1.19 to 1.93 except 2.05 in January i.e., almost stable. PUBALI bank has the average gross return ranges from 1.27 to 1.41 except 3.36 in August, 2.0 in November. The average gross return of SIBL, SOUTHEAST bank, STANDARD bank are ranging from 1.14 to 1.95 i.e., stable in nature. UTTARA bank's average values are almost stable lying between 1.18 and 1.46 with an extreme value 2.17 in December. From the above discussion it 
is clear that the average gross returns vary more by month than by year.

Table 1. Descriptive statistics of gross returns of 15 banks index by month

\begin{tabular}{|c|c|c|c|c|c|c|c|c|c|c|c|c|c|c|}
\hline SL & Bank name & JAN & FEB & MAR & APR & MAY & JUNE & JULY & AUG & SEP & OCT & NOV & DEC & Ave \\
\hline 1 & $\mathrm{ABB}$ & $\begin{array}{c}1.18 \\
(0.73)\end{array}$ & $\begin{array}{c}1.13 \\
(0.58)\end{array}$ & $\begin{array}{c}1.17 \\
(0.74)\end{array}$ & $\begin{array}{c}1.13 \\
(0.57)\end{array}$ & $\begin{array}{c}1.24 \\
(1.01)\end{array}$ & $\begin{array}{c}1.21 \\
(0.98)\end{array}$ & $\begin{array}{c}1.17 \\
(0.78)\end{array}$ & $\begin{array}{c}1.13 \\
(0.72)\end{array}$ & $\begin{array}{c}1.16 \\
(0.68)\end{array}$ & $\begin{array}{c}1.31 \\
(1.33)\end{array}$ & $\begin{array}{c}1.21 \\
(0.96)\end{array}$ & $\begin{array}{c}1.15 \\
(0.72)\end{array}$ & 1.18 \\
\hline 2 & ARB & $\begin{array}{c}1.75 \\
(2.65)\end{array}$ & $\begin{array}{c}1.43 \\
(1.84)\end{array}$ & $\begin{array}{c}1.89 \\
(4.18)\end{array}$ & $\begin{array}{c}1.43 \\
(1.56)\end{array}$ & $\begin{array}{c}1.67 \\
(3.37)\end{array}$ & $\begin{array}{c}1.46 \\
(1.32)\end{array}$ & $\begin{array}{c}1.53 \\
(2.47)\end{array}$ & $\begin{array}{c}2.02 \\
(4.58)\end{array}$ & $\begin{array}{c}1.51 \\
(2.15)\end{array}$ & $\begin{array}{c}1.36 \\
(1.39)\end{array}$ & $\begin{array}{c}3.22 \\
(16.39)\end{array}$ & $\begin{array}{c}2.20 \\
(6.66)\end{array}$ & 1.79 \\
\hline 3 & СТВ & $\begin{array}{c}1.33 \\
(1.22)\end{array}$ & $\begin{array}{c}1.30 \\
(1.55)\end{array}$ & $\begin{array}{c}1.55 \\
(1.87)\end{array}$ & $\begin{array}{c}1.46 \\
(1.97)\end{array}$ & $\begin{array}{c}1.52 \\
(2.70)\end{array}$ & $\begin{array}{c}1.46 \\
(1.78)\end{array}$ & $\begin{array}{c}1.41 \\
(1.64)\end{array}$ & $\begin{array}{c}1.43 \\
(1.75)\end{array}$ & $\begin{array}{c}2.04 \\
(9.01)\end{array}$ & $\begin{array}{c}1.43 \\
(1.50)\end{array}$ & $\begin{array}{c}1.39 \\
(1.82)\end{array}$ & $\begin{array}{c}1.30 \\
(1.36)\end{array}$ & 1.47 \\
\hline 4 & DHB & $\begin{array}{c}2.87 \\
(13.26)\end{array}$ & $\begin{array}{c}1.47 \\
(1.69)\end{array}$ & $\begin{array}{c}2.85 \\
(30.27)\end{array}$ & $\begin{array}{l}1.61 \\
(2.46)\end{array}$ & $\begin{array}{c}2.67 \\
(13.5)\end{array}$ & $\begin{array}{c}2.69 \\
(9.33)\end{array}$ & $\begin{array}{c}1.63 \\
(2.99)\end{array}$ & $\begin{array}{c}1.90 \\
(3.32)\end{array}$ & $\begin{array}{c}1.85 \\
(3.87)\end{array}$ & $\begin{array}{c}2.54 \\
(20.80)\end{array}$ & $\begin{array}{c}3.51 \\
(21.88)\end{array}$ & $\begin{array}{c}1.57 \\
(1.91)\end{array}$ & 2.97 \\
\hline 5 & EXB & $\begin{array}{c}1.34 \\
(2.01)\end{array}$ & $\begin{array}{c}1.13 \\
(0.61)\end{array}$ & $\begin{array}{c}1.56 \\
(2.03)\end{array}$ & $\begin{array}{c}1.31 \\
(1.20)\end{array}$ & $\begin{array}{c}1.24 \\
(0.93)\end{array}$ & $\begin{array}{c}1.22 \\
(0.86)\end{array}$ & $\begin{array}{c}1.20 \\
(0.86)\end{array}$ & $\begin{array}{c}1.25 \\
(1.29)\end{array}$ & $\begin{array}{c}1.21 \\
(0.95)\end{array}$ & $\begin{array}{c}1.25 \\
(1.06)\end{array}$ & $\begin{array}{l}1.16 \\
(0.75)\end{array}$ & $\begin{array}{c}1.28 \\
(0.92)\end{array}$ & 1.26 \\
\hline 6 & IFB & $\begin{array}{c}2.12 \\
(4.88)\end{array}$ & $\begin{array}{c}1.40 \\
(1.38)\end{array}$ & $\begin{array}{c}1.40 \\
(1.64)\end{array}$ & $\begin{array}{c}1.54 \\
(1.66)\end{array}$ & $\begin{array}{c}1.45 \\
(1.49)\end{array}$ & & & & & & & $\begin{array}{c}2.01 \\
(4.21)\end{array}$ & 1.74 \\
\hline 7 & ISB & $\begin{array}{c}1.48 \\
(3.83)\end{array}$ & $\begin{array}{c}1.33 \\
(1.57)\end{array}$ & $\begin{array}{c}1.27 \\
(0.88)\end{array}$ & $\begin{array}{c}1.34 \\
(1.26)\end{array}$ & $\begin{array}{c}1.39 \\
(1.35)\end{array}$ & $\begin{array}{c}2.22 \\
(9.91)\end{array}$ & $\begin{array}{c}1.63 \\
(5.30)\end{array}$ & $\begin{array}{l}1.45 \\
(2.63)\end{array}$ & $\begin{array}{c}1.42 \\
(1.62)\end{array}$ & $\begin{array}{c}1.30 \\
(1.32)\end{array}$ & $\begin{array}{c}1.57 \\
(2.22)\end{array}$ & $\begin{array}{c}1.59 \\
(3.16)\end{array}$ & 1.50 \\
\hline 8 & NLB & $\begin{array}{c}1.38 \\
(2.59)\end{array}$ & $\begin{array}{c}1.15 \\
(0.68)\end{array}$ & $\begin{array}{c}1.25 \\
(1.43)\end{array}$ & $\begin{array}{c}1.15 \\
(0.63)\end{array}$ & $\begin{array}{c}1.16 \\
(0.69)\end{array}$ & $\begin{array}{c}1.18 \\
(0.73)\end{array}$ & $\begin{array}{c}1.06 \\
(0.49)\end{array}$ & $\begin{array}{c}1.59 \\
(5.23)\end{array}$ & $\begin{array}{c}1.15 \\
(0.68)\end{array}$ & $\begin{array}{c}1.17 \\
(0.70)\end{array}$ & $\begin{array}{c}1.11 \\
(0.57)\end{array}$ & $\begin{array}{c}1.11 \\
(0.53)\end{array}$ & 1.20 \\
\hline 9 & $\mathrm{NCB}$ & $\begin{array}{c}1.25 \\
(0.99)\end{array}$ & $\begin{array}{c}1.18 \\
(0.71)\end{array}$ & $\begin{array}{c}1.30 \\
(1.21)\end{array}$ & $\begin{array}{c}1.38 \\
(1.79)\end{array}$ & $\begin{array}{c}1.22 \\
(0.89)\end{array}$ & $\begin{array}{c}1.29 \\
(1.02)\end{array}$ & $\begin{array}{c}1.20 \\
(0.78)\end{array}$ & $\begin{array}{c}1.33 \\
(1.55)\end{array}$ & $\begin{array}{c}1.28 \\
(1.21)\end{array}$ & $\begin{array}{c}1.18 \\
(0.74)\end{array}$ & $\begin{array}{c}1.31 \\
(1.67)\end{array}$ & $\begin{array}{c}1.29 \\
(1.85)\end{array}$ & 1.27 \\
\hline 10 & ONB & $\begin{array}{c}2.05 \\
(9.33)\end{array}$ & $\begin{array}{c}1.41 \\
(1.37)\end{array}$ & $\begin{array}{c}1.47 \\
(1.71)\end{array}$ & $\begin{array}{c}1.73 \\
(4.39)\end{array}$ & $\begin{array}{c}1.92 \\
(5.18)\end{array}$ & $\begin{array}{c}1.44 \\
(1.49)\end{array}$ & $\begin{array}{c}1.19 \\
(0.97)\end{array}$ & $\begin{array}{c}1.93 \\
(6.85)\end{array}$ & $\begin{array}{c}1.28 \\
(1.12)\end{array}$ & $\begin{array}{c}1.44 \\
(1.73)\end{array}$ & $\begin{array}{c}1.39 \\
(1.72)\end{array}$ & $\begin{array}{c}1.32 \\
(1.21)\end{array}$ & 1.55 \\
\hline 11 & PBB & $\begin{array}{c}1.39 \\
(1.46)\end{array}$ & $\begin{array}{c}1.27 \\
(1.06)\end{array}$ & $\begin{array}{c}1.31 \\
(1.18)\end{array}$ & $\begin{array}{c}1.36 \\
(1.48)\end{array}$ & $\begin{array}{c}1.38 \\
(1.88)\end{array}$ & $\begin{array}{c}1.34 \\
(1.17)\end{array}$ & $\begin{array}{c}1.32 \\
(1.14)\end{array}$ & $\begin{array}{c}3.36 \\
(20.6)\end{array}$ & $\begin{array}{c}1.41 \\
(1.37)\end{array}$ & $\begin{array}{c}1.34 \\
(1.21)\end{array}$ & $\begin{array}{c}2.00 \\
(4.54)\end{array}$ & $\begin{array}{c}1.30 \\
(1.10)\end{array}$ & 1.57 \\
\hline 12 & SJB & $\begin{array}{c}1.24 \\
(1.01)\end{array}$ & $\begin{array}{c}1.27 \\
(1.00)\end{array}$ & $\begin{array}{c}1.25 \\
(0.93)\end{array}$ & $\begin{array}{c}1.40 \\
(1.31)\end{array}$ & $\begin{array}{c}1.18 \\
(0.74)\end{array}$ & $\begin{array}{c}1.31 \\
(1.04)\end{array}$ & $\begin{array}{c}2.75 \\
(17.91)\end{array}$ & $\begin{array}{c}1.37 \\
(1.76)\end{array}$ & $\begin{array}{c}1.30 \\
(1.17)\end{array}$ & $\begin{array}{c}2.84 \\
(18.08)\end{array}$ & $\begin{array}{c}1.30 \\
(1.18)\end{array}$ & $\begin{array}{c}1.29 \\
(1.82)\end{array}$ & 1.54 \\
\hline 13 & SEB & $\begin{array}{c}1.24 \\
(0.93)\end{array}$ & $\begin{array}{c}1.95 \\
(7.77)\end{array}$ & $\begin{array}{c}1.54 \\
(2.28)\end{array}$ & $\begin{array}{c}1.22 \\
(1.01)\end{array}$ & $\begin{array}{c}1.28 \\
(0.98)\end{array}$ & $\begin{array}{c}1.42 \\
(1.42)\end{array}$ & $\begin{array}{c}1.27 \\
(1.26)\end{array}$ & $\begin{array}{c}1.40 \\
(2.02)\end{array}$ & $\begin{array}{c}1.93 \\
(5.92)\end{array}$ & $\begin{array}{c}1.47 \\
(2.08)\end{array}$ & $\begin{array}{c}1.36 \\
(2.13)\end{array}$ & $\begin{array}{c}1.46 \\
(2.73)\end{array}$ & 1.46 \\
\hline 14 & STB & $\begin{array}{c}1.27 \\
(1.06)\end{array}$ & $\begin{array}{c}1.14 \\
(0.65)\end{array}$ & $\begin{array}{c}1.55 \\
(2.70)\end{array}$ & $\begin{array}{c}1.31 \\
(1.33)\end{array}$ & $\begin{array}{c}1.29 \\
(0.99)\end{array}$ & $\begin{array}{c}1.40 \\
(1.48)\end{array}$ & $\begin{array}{c}1.34 \\
(1.29)\end{array}$ & $\begin{array}{c}1.59 \\
(2.75)\end{array}$ & $\begin{array}{c}1.24 \\
(0.94)\end{array}$ & $\begin{array}{c}1.26 \\
(0.89)\end{array}$ & $\begin{array}{c}1.30 \\
(1.10)\end{array}$ & $\begin{array}{c}1.36 \\
(1.50)\end{array}$ & 1.34 \\
\hline 15 & UTB & $\begin{array}{c}1.40 \\
(1.36)\end{array}$ & $\begin{array}{c}1.18 \\
(0.80)\end{array}$ & $\begin{array}{c}1.53 \\
(2.12)\end{array}$ & $\begin{array}{c}1.23 \\
(1.09)\end{array}$ & $\begin{array}{c}1.46 \\
(1.60)\end{array}$ & $\begin{array}{c}1.42 \\
(1.70)\end{array}$ & $\begin{array}{c}1.33 \\
(1.48)\end{array}$ & $\begin{array}{c}1.36 \\
(1.22)\end{array}$ & $\begin{array}{c}1.36 \\
(1.09)\end{array}$ & $\begin{array}{c}1.39 \\
(1.19)\end{array}$ & $\begin{array}{c}1.29 \\
(1.18)\end{array}$ & $\begin{array}{c}2.17 \\
(21.57)\end{array}$ & 1.68 \\
\hline
\end{tabular}

*Figure within parenthesis indicates the value of standard error(se)

Next section we would like to present the normality test of the dataset.

Normality test

Normality of any data set is a big challenge for fitting any model of a time series data. Since the return data does not show the normality and as well as non stationary so here log return data is considered in this study for analysis. Figure 1 shows the histograms of daily log returns of selected 15 banks. From the all diagrams it is obvious that the daily log returns for all banks are almost normally distributed. 


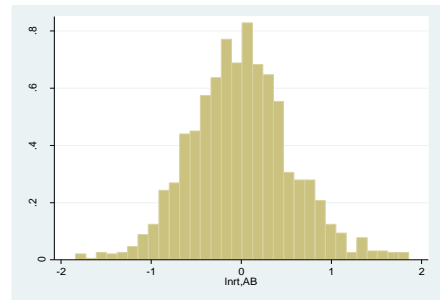

AB bank

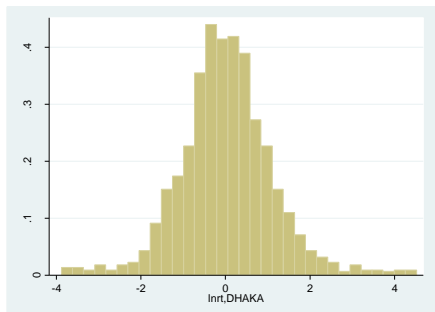

DHAKA bank

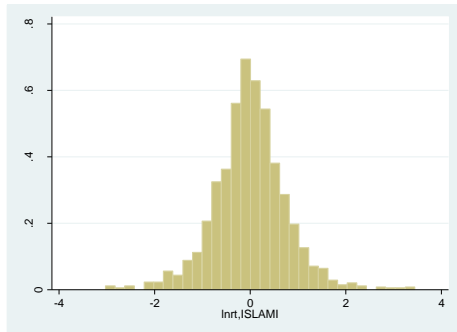

ISLAMI bank

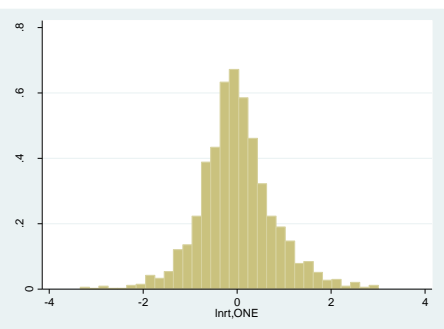

ONE bank

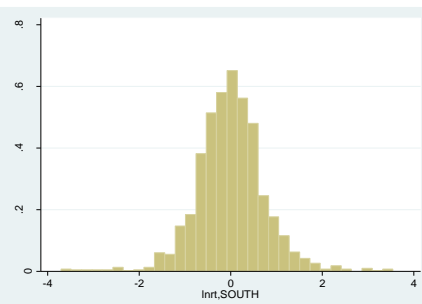

SOUTHEAST bank

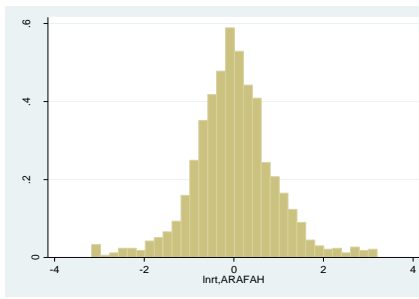

AL ARAFAH bank

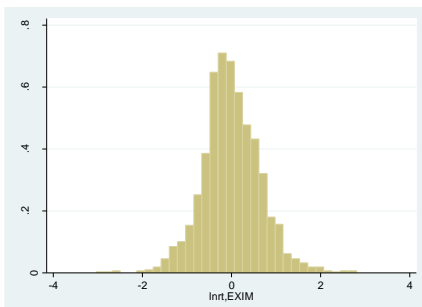

EXIM bank

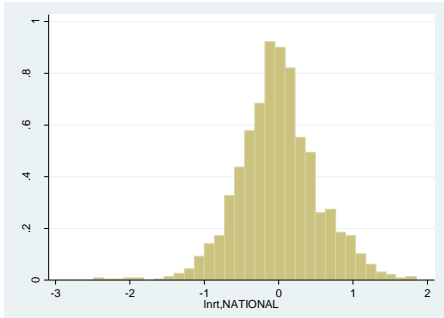

NATIONAL bank

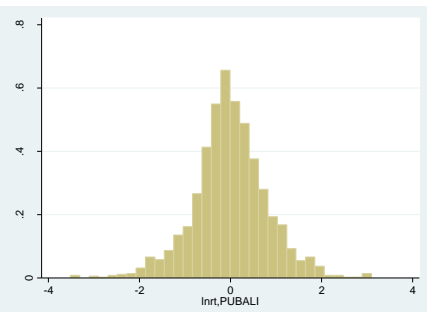

PUBALI bank

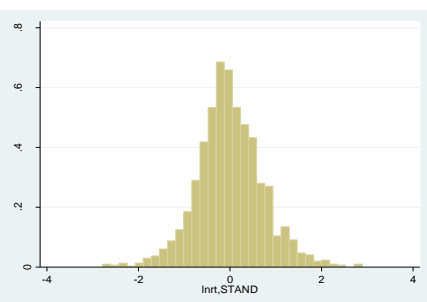

STANDARD bank

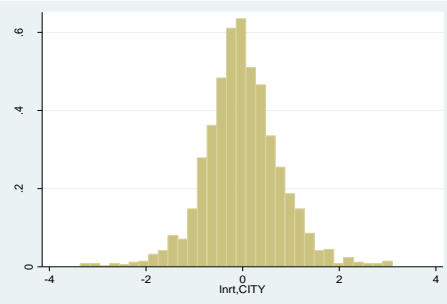

CITY bank

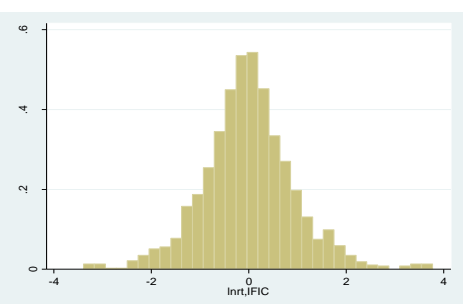

IFIC bank

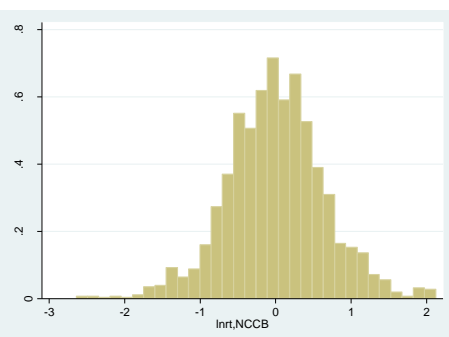

NCC bank

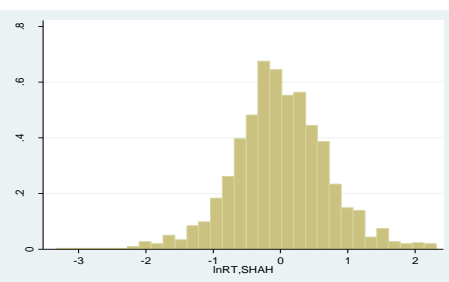

SHAHJALAL bank

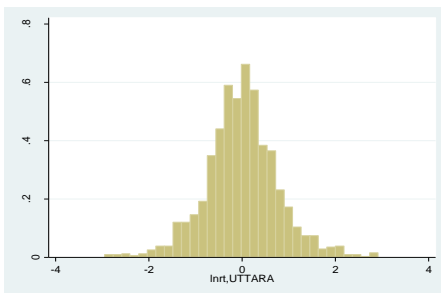

UTTARA bank

Figure 1. The histogram of log return of selected banks in CSE 50 index

For fitting any model of time series data, stationarity is an important issue. For these data set, the stationarity are tested for different companies by using Stata software with graphical and statistical method. In statistical method, ADF unit root test is used to check the stationarity of data set which are described in the Table 2. Significant unit root test statistic indicate the stationarity of data. For graphical method the line diagram of log return for different banks are shown in Figure 2. The line graph of $\log$ returns for every bank shows the random variation 
around zero, implies log return variable are stationarity and used to predict the return for these banks. From the Figure 2, it is obvious that there are some ups and down in the daily log returns but the Figures confer the stationary i.e., the random shocks follow the white noise stationary process. So it can be concluded that the daily $\log$ returns of all selected companies are stationary in nature.

Table 2. Augmented Dickey-Fuller test Statistic for Stationarity of log return of selected banks in CSE 50 index

\begin{tabular}{clccc}
\hline SI No. & Bank Name & Short Name & Test Statistic & P-value \\
\hline 1. & AB bank & ABB & -12.798 & $\mathrm{p}<0.001$ \\
2. & AL ARAFAH bank & ARB & -53.222 & $\mathrm{p}<0.001$ \\
3. & CITY bank & CTB & -52.286 & $\mathrm{p}<0.001$ \\
4. & DHAKA bank & DHB & -52.226 & $\mathrm{p}<0.001$ \\
5. & EXIM bank & EXB & -50.737 & $\mathrm{p}<0.001$ \\
6. & IFIC bank & IFB & -54.247 & $\mathrm{p}<0.001$ \\
7. & ISLAMI bank & ISB & -55.485 & $\mathrm{p}<0.001$ \\
8. & NATIONAL bank & NCB & -50.730 & $\mathrm{p}<0.001$ \\
9. & NCC bank & ONB & -49.897 & $\mathrm{p}<0.001$ \\
10. & ONE bank & PBB & -53.482 & $\mathrm{p}<0.001$ \\
11. & PUBALI bank & SJB & -56.978 & $\mathrm{p}<0.001$ \\
12. & SHAHJALAL bank & SEB & -51.618 & $\mathrm{p}<0.001$ \\
13. & SOUTHEAST bank & STB & -56.499 & $\mathrm{p}<0.001$ \\
14. & STANDARD bank & UTB & -54.959 & $\mathrm{p}<0.001$ \\
15. & UTTARA bank & $\mathrm{p}<0.001$ \\
\hline
\end{tabular}

For fitting and estimating any statistical model it is essential to test the multicollinearity among the independent variables. Variance Inflating Factor is an important tool to check the multicollinearity. VIF up to 10 indicates weak multicollinearity and need not to make correction whereas more than 10 need to take a remedial measures. The average VIF for all companies are less than 10, indicate the not severity of multicollinearity and can use these explanatory variables $\Delta \mathrm{Y}_{\mathrm{t}}, \Delta^{2} \mathrm{Y}_{\mathrm{t}}, \Delta \mathrm{X}_{\mathrm{t}}$ and $\Delta^{2} \mathrm{X}_{\mathrm{t}}$ in the model. From the Table 3 it is observed that the mean VIF is more than 5.00 for $\mathrm{AB}$ bank, CITY bank, IFIC bank, ISLAMI bank, NATIONAL bank, ONE bank, SOUTHEAST bank, STANDARD bank and UTTARA bank.

\section{ARCH Effect}

Generally in time series data, after fitting a mean regression model ARCH effect is tested for building a volatility model. The test is based on the residuals of this mean regression model. Lagrange multiplier (LM) test is the common method to test the ARCH effect. Significant LM test statistic indicate the situation of having ARCH effect. Table 4 shows the LM test for the selected banks. From the table it is seen that all the test statistics' are statistically significant. So, it can be concluded that the data getting from all the banks have the conditional heteroscadisticity in the behavior of their residuals. From the above test it is also observed that the test statistic is significant with two period lags for AL ARAFAH bank, DHAKA bank, IFIC bank, ISLAMI bank, NCC bank, SHAHJALAL bank and returns for the rest of banks are significant with one period lag.

\section{Parkinson's Volatility}

There are several measures of volatility. Among these measures Parkinson's extreme value estimator based on intra-day high and low price of an asset is more efficient. Figure 3 shows the Parkinson's monthly volatility of the selected banks in CSE 50 index. From the line diagrams of different banks, it is observed that there is complete randomness in monthly volatility of every companies. But the volatility is severe in $\mathrm{AB}$ bank, $\mathrm{AL}$ ARAFAH bank, DHAKA bank, EXIM bank, IFIC bank and NATIONAL bank. From this figure it is observed that $\mathrm{AB}$ bank has the maximum volatility 0.15 in May of 2010, EXIM bank has its highest volatility 0.10 in May of 2010, ISLAMI bank has the highest volatility 0.16 in July of 2009 respectively. 


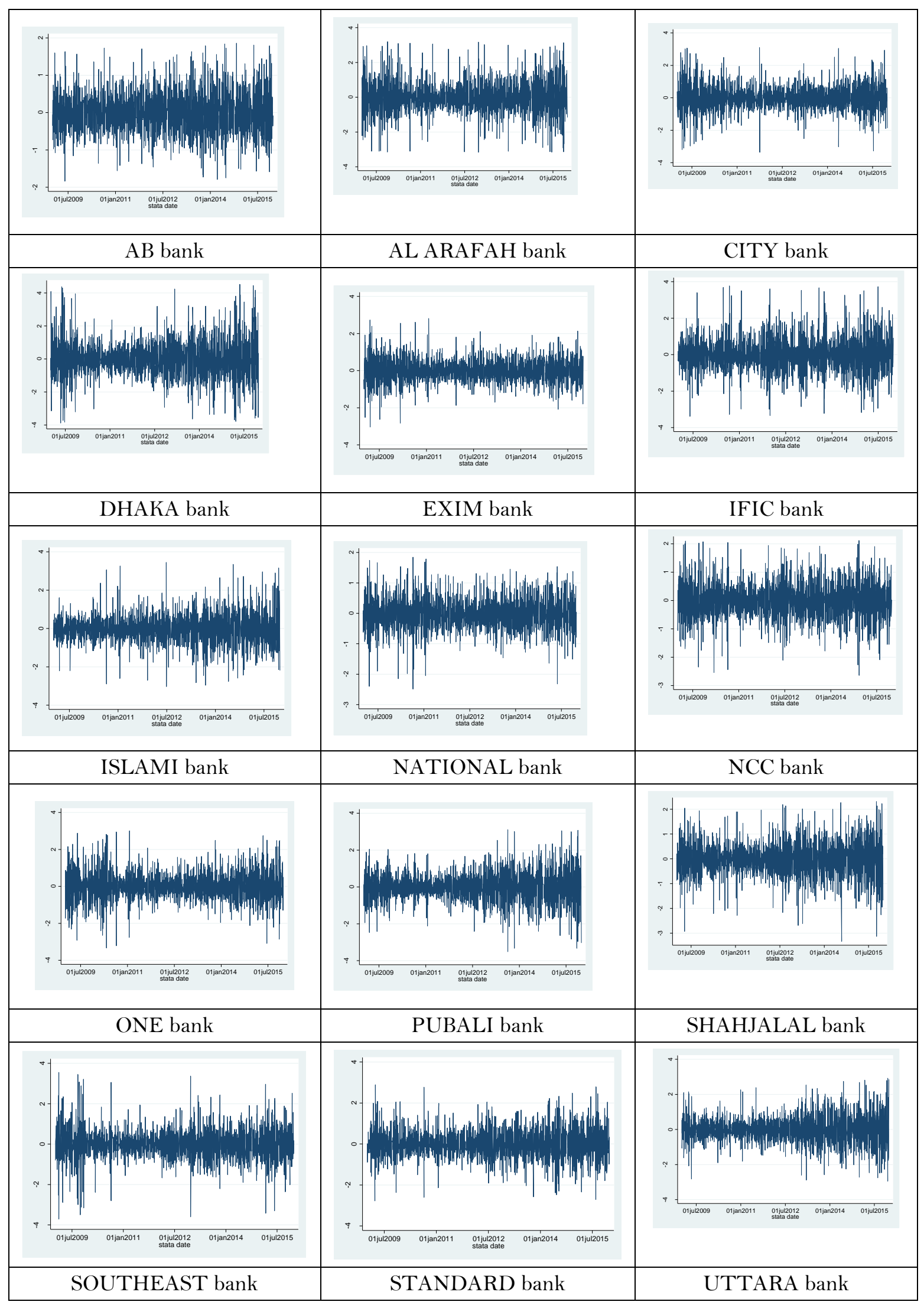

Figure 2. The histogram of log return of selected banks in CSE 30 index 
Table 3. Variance Inflating Factor (VIF) for regression

\begin{tabular}{|c|c|c|c|c|c|c|}
\hline SL & Bank Name & $\Delta \mathrm{Y}_{\mathrm{t}}$ & $\Delta^{2} Y_{t}$ & $\Delta X_{t}$ & $\Delta^{2} X_{t}$ & Average VIF \\
\hline 1 & AB bank & 4.55 & 4.43 & 10.61 & 9.72 & 7.33 \\
\hline 2 & AL ARAFAH bank & 6.06 & 6.01 & 1.94 & 1.94 & 3.99 \\
\hline 3 & CITY bank & 5.39 & 5.35 & 10.19 & 8.28 & 7.30 \\
\hline 4 & DHAKA bank & 5.63 & 5.61 & 1.01 & 5.06 & 4.33 \\
\hline 5 & EXIM bank & 5.27 & 5.15 & 1.75 & 1.78 & 3.49 \\
\hline 6 & IFIC bank & 5.28 & 5.23 & 8.98 & 9.08 & 7.14 \\
\hline 7 & ISLAMI bank & 5.22 & 5.21 & 9.07 & 10.09 & 7.65 \\
\hline 8 & NATIONAL bank & 5.11 & 5.10 & 10.28 & 10.33 & 7.71 \\
\hline 9 & NCC bank & 5.12 & 5.09 & 1.93 & 1.98 & 3.53 \\
\hline 10 & ONE bank & 5.03 & 5.00 & 7.13 & 7.20 & 6.09 \\
\hline 11 & PUBALI bank & 5.72 & 5.67 & 1.97 & 2.01 & 3.84 \\
\hline 12 & SHAHJALAL bank & 5.62 & 5.47 & 2.00 & 2.09 & 3.80 \\
\hline 13 & SOUTHEAST bank & 5.17 & 5.17 & 9.21 & 10.26 & 7.45 \\
\hline 14 & STANDARD bank & 5.74 & 5.75 & 8.28 & 10.35 & 8.03 \\
\hline 15 & UTTARA bank & 5.74 & 5.73 & 10.99 & 9.02 & 7.87 \\
\hline \multicolumn{7}{|c|}{ Table 4. Lagrange Multiplier test for ARCH effect } \\
\hline SI & Bank Name & & & Chi-Square & & P-value \\
\hline 1. & $\mathrm{AB}$ bank & & & 16.339 & & $\mathrm{p}<0.01$ \\
\hline 2. & AL ARAFAH bank & & & 27.569 & & $\mathrm{p}<0.001$ \\
\hline 3. & CITY bank & & & 25.469 & & $\mathrm{p}<0.001$ \\
\hline 4. & DHAKA bank & & & 27.447 & & $\mathrm{p}<0.001$ \\
\hline 5. & EXIM bank & & & 106.542 & & $\mathrm{p}<0.001$ \\
\hline 6. & IFIC bank & & & 35.239 & & $\mathrm{p}<0.001$ \\
\hline 7. & ISLAMI bank & & & 13.426 & & $\mathrm{p}<0.01$ \\
\hline 8. & NATIONAL bank & & & 70.543 & & $\mathrm{p}<0.001$ \\
\hline 9. & NCC bank & & & 11.276 & & $\mathrm{p}<0.01$ \\
\hline 10. & ONE bank & & & 34.179 & & $\mathrm{p}<0.001$ \\
\hline 11. & PUBALI bank & & & 29.093 & & $\mathrm{p}<0.001$ \\
\hline 12. & SHAHJALAL bank & & & 10.244 & & $\mathrm{p}<0.01$ \\
\hline 13. & SOUTHEAST bank & & & 73.581 & & $\mathrm{p}<0.001$ \\
\hline 14. & STANDARD bank & & & 46.206 & & $\mathrm{p}<0.001$ \\
\hline 15. & UTTARA bank & & & 15.645 & & $\mathrm{p}<0.01$ \\
\hline
\end{tabular}

Table 5. Stata output of ARCH family regression for AL ARAFAH bank

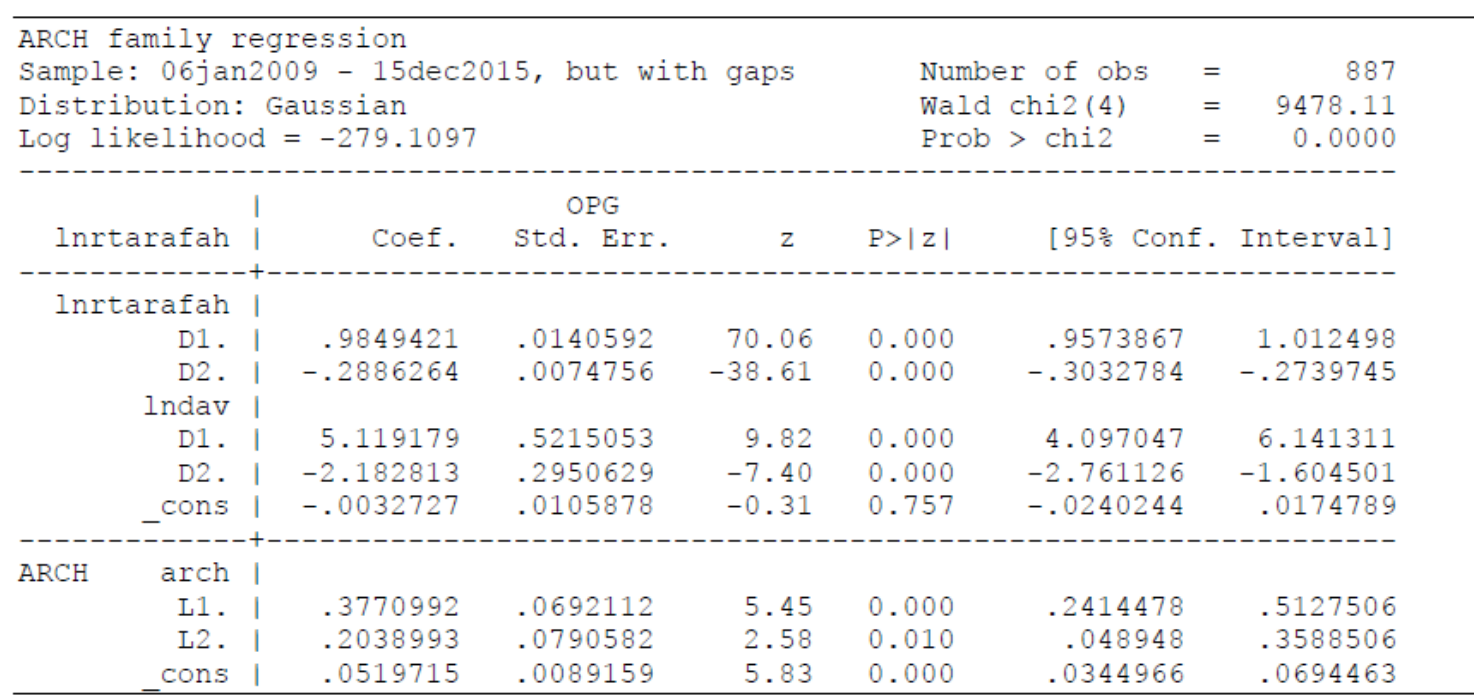

Similarly the dynamic regression model with volatility regression of ARCH effect for others banks are run and the parameters for corresponding banks are shown in Table 6 and Table 7. From the joint estimation of mean model and volatility model for the selected 15 banks, it is observed that 1st difference of both log return and $\log$ daily average have the significant positive effect on log daily return but the 2nd difference have the significant opposite effect on the daily log return. Moreover, the positive effects are higher than negative effects in their magnitude. The fitted dynamic models are chosen with minimum AIC and BIC value. However, the above fitted model cannot be used in forecasting due to its complex form having the difference terms of both dependent variable and independent variable as a explanatory variable. So, in the Table 8 , the proposed fitted modified 
ARDL model and volatility model will be described for forecasting which removes the complexity of the previous fitted model.

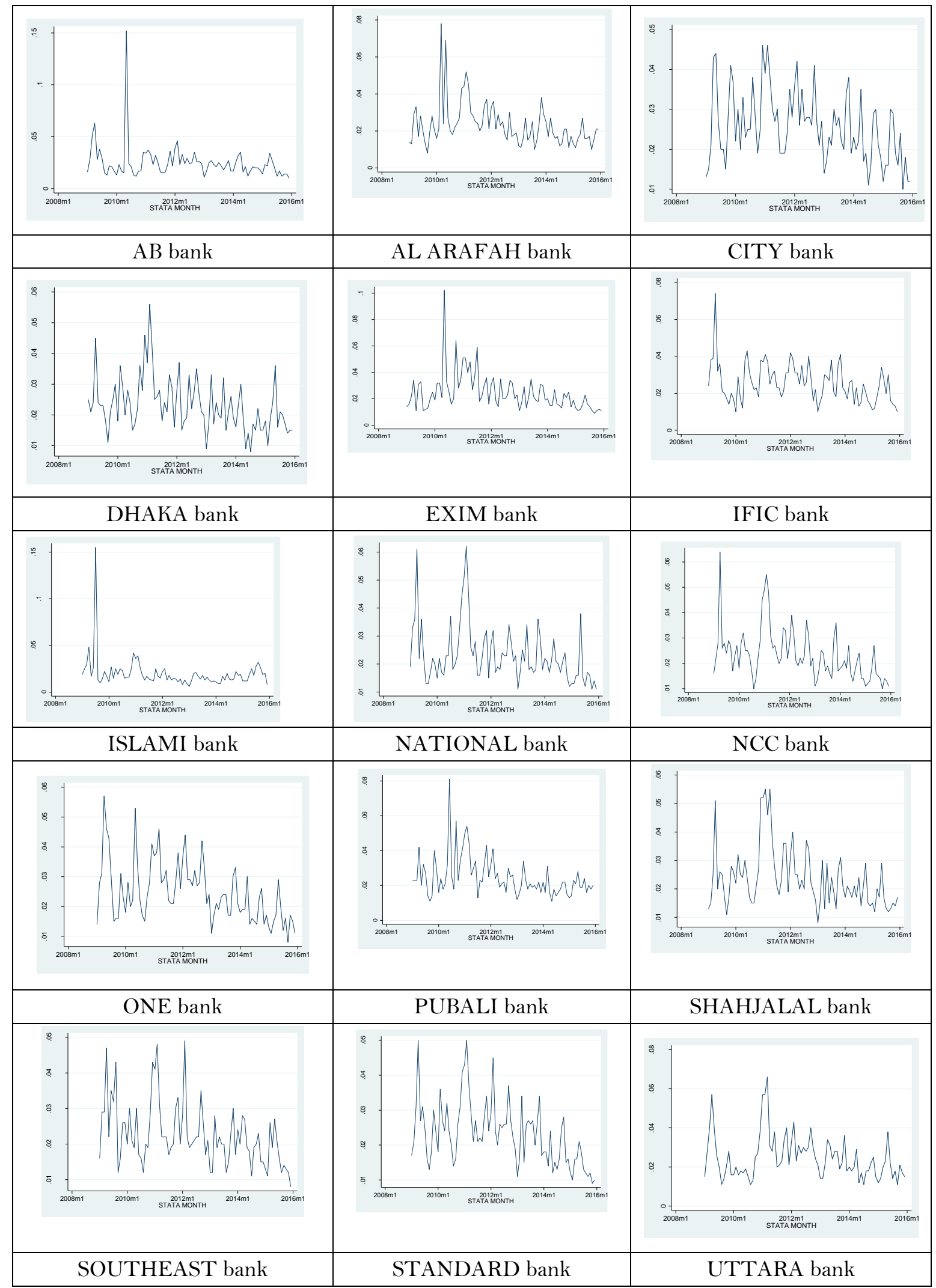

Figure 3. Parkinson's volatility of selected companies in CSE 50 index 
Fitted volatility model for different companies are shown in the Table 7. Six out of 15 banks have significant ARCH effect with 2 period lags and rest of the companies have significant ARCH effect with 1 period lag.

Table 6. Summary table of the dynamic model for selected banks

\begin{tabular}{ccccccc}
\hline SL & Bank's name & constant & $\Delta y_{+}$ & $\Delta^{2} y_{+}$ & $\Delta x_{+}$ & $\Delta^{2} x_{+}$ \\
\hline 1 & ABB & -0.01362 & 1.02999 & -0.31824 & 3.07414 & -2.65637 \\
2 & ARB & -0.00327 & 0.98494 & -0.28863 & 5.11918 & -2.18281 \\
3 & CTB & 0.02985 & 1.02591 & -0.31502 & 3.10114 & -2.60071 \\
4 & DHB & 0.00577 & 1.01457 & -0.30912 & 5.70067 & -3.42112 \\
5 & EXB & -0.00166 & 0.96361 & -0.28410 & 5.24181 & -2.54131 \\
6 & IFB & -0.00013 & 1.02400 & -0.30655 & 4.52883 & -3.30037 \\
7 & ISB & -0.00938 & 0.99477 & -0.29454 & 1.82262 & -1.98810 \\
8 & NLB & 0.00015 & 1.00897 & -0.30254 & 2.44069 & -2.22615 \\
9 & NCB & 0.00656 & 0.99734 & -0.29905 & 4.87396 & -2.32871 \\
10 & ONB & 0.00655 & 0.98438 & -0.29678 & 2.60703 & -2.17144 \\
11 & PBB & -0.00521 & 0.99511 & -0.29371 & 4.01448 & -2.41084 \\
12 & SJB & -0.00388 & 0.96795 & -0.27849 & 5.34697 & -2.99872 \\
13 & SEB & 0.00178 & 0.98689 & -0.28783 & 2.98244 & -2.41354 \\
14 & STB & -0.00214 & 0.96840 & -0.28437 & 2.47444 & -1.97796 \\
15 & UTB & -0.00624 & 1.01361 & -0.30829 & 1.52853 & -1.50736 \\
\hline
\end{tabular}

Table 7. Fitted Volatility model for selected 15 banks listed in CSE

\begin{tabular}{|c|c|c|}
\hline SL & Company name & Fitted Volatility model \\
\hline 1 & $\mathrm{ABB}$ & $\hat{\sigma}_{t}^{2}=\underset{(0.000)}{0.03729}+\underset{(0.001)}{0.20143} a_{t-1}^{2}$ \\
\hline 2 & $\mathrm{ARB}$ & $\hat{\sigma}_{t}^{2}=\underset{(0.000)}{0.05197}+\underset{(0.000)}{0.37710} a_{t-1}^{2}+\underset{(0.010)}{0.20390} a_{t-2}^{2}$ \\
\hline 3 & СТВ & $\hat{\sigma}_{t}^{2}=\underset{(0.000)}{0.05253}+\underset{(0.000)}{0.39508} a_{t-1}^{2}$ \\
\hline 4 & DHB & $\hat{\sigma}_{t}^{2}=\underset{(0.000)}{0.067055}+\underset{(0.000)}{0.4298817} a_{t-1}^{2}+\underset{(0.011)}{0.1778649} a_{t-2}^{2}$ \\
\hline 5 & EXB & $\hat{\sigma}_{t}^{2}=\underset{(0.000)}{0.03592}+\underset{(0.000)}{0.35367} a_{t-1}^{2}$ \\
\hline 6 & IFB & $\hat{\sigma}_{t}^{2}=\underset{(0.000)}{0.05891}+\underset{(0.000)}{0.36384} a_{t-1}^{2}+\underset{(0.018)}{0.11006} a_{t-2}^{2}$ \\
\hline 7 & ISB & $\hat{\sigma}_{t}^{2}=\underset{(0.000)}{0.03685}+\underset{(0.000)}{0.25881} a_{t-1}^{2}+\underset{(0.001)}{0.25019} a_{t-2}^{2}$ \\
\hline 8 & NBB & $\hat{\sigma}_{t}^{2}=\underset{(0.000)}{0.02779}+\underset{(0.000)}{0.34681} a_{t-1}^{2}$ \\
\hline 9 & $\mathrm{NCB}$ & $\hat{\sigma}_{t}^{2}=\underset{(0.000)}{0.02554}+\underset{(0.000)}{0.32417} a_{t-1}^{2}+\underset{(0.002)}{0.27001} a_{t-1}^{2}$ \\
\hline
\end{tabular}




\begin{tabular}{|c|c|c|}
\hline SL & Company name & Fitted Volatility model \\
\hline 10 & ONB & $\hat{\sigma}_{t}^{2}=\underset{(0.000)}{0.05313}+\underset{(0.000)}{0.34861} a_{t-1}^{2}$ \\
\hline 11 & PBB & $\hat{\sigma}_{t}^{2}=\underset{(0.000)}{0.06276}+\underset{(0.000)}{0.21490} a_{t-1}^{2}$ \\
\hline 12 & SJB & $\hat{\sigma}_{t}^{2}=\underset{(0.000)}{0.03841}+\underset{(0.000)}{0.19246} a_{t-1}^{2}+\underset{(0.005)}{0.16828} a_{t-2}^{2}$ \\
\hline 13 & SEB & $\hat{\sigma}_{t}^{2}=\underset{(0.000)}{0.04127}+\underset{(0.000)}{0.56809} a_{t-1}^{2}$ \\
\hline 14 & STB & $\hat{\sigma}_{t}^{2}=\underset{(0.000)}{0.04443}+\underset{(0.000)}{0.35269} a_{t-1}^{2}$ \\
\hline 15 & UTB & $\hat{\sigma}_{t}^{2}=\underset{(0.000)}{0.06593}+\underset{(0.006)}{0.17356} a_{t-1}^{2}$ \\
\hline
\end{tabular}

*Figure in parenthesis indicate the significant $\mathrm{P}$ value for estimated coefficients

Table 8. Parameters of proposed modified ARDL $(2,2)$ regression model

\begin{tabular}{|c|c|c|c|c|c|c|c|}
\hline \multirow[t]{2}{*}{ SL } & \multirow[t]{2}{*}{ Company name } & \multirow{2}{*}{$\begin{array}{l}\text { Intercept } \\
\left(\beta_{0}^{\prime}\right)\end{array}$} & \multicolumn{5}{|c|}{ Explanatory variables } \\
\hline & & & $\begin{array}{l}\mathrm{Y}_{\mathrm{t}-1} \\
\left(\beta_{1}^{\prime}\right)\end{array}$ & $\begin{array}{l}\mathrm{Y}_{\mathrm{t}-2} \\
\left(\beta_{2}^{\prime}\right)\end{array}$ & $\begin{array}{c}\hat{\wedge} \mathrm{X}_{\mathrm{t}} \\
\left(\hat{\alpha}_{0}^{\prime}\right)\end{array}$ & $\begin{array}{l}\mathrm{X}_{\mathrm{t}-1} \\
\left(\alpha_{1}^{\prime}\right)\end{array}$ & $\begin{array}{c}X_{t-2} \\
\left(\alpha_{2}^{\prime}\right)\end{array}$ \\
\hline 1 & $\mathrm{ABB}$ & -0.04724 & -1.36508 & -1.10402 & 1.44927 & 7.76590 & -9.21518 \\
\hline 2 & ARB & -0.01078 & -1.34248 & -0.95042 & 9.66914 & -2.48137 & -7.18777 \\
\hline 3 & СТB & 0.02976 & -0.39471 & -0.31410 & 0.49896 & 2.09413 & -2.59309 \\
\hline 4 & DHB & 0.01960 & -1.13455 & -1.04944 & 7.73880 & 3.87555 & -11.6144 \\
\hline 5 & EXB & -0.00518 & -1.23386 & -0.88645 & 8.42641 & -0.49671 & -7.92970 \\
\hline 6 & IFB & -0.00045 & -1.45539 & -1.08579 & 4.35118 & 7.33856 & -11.6897 \\
\hline 7 & ISB & -0.03130 & -1.35343 & -0.98257 & -0.55204 & 7.18435 & -6.63230 \\
\hline 8 & NBB & 3.43689 & -1.37579 & -1.03055 & 0.73079 & 6.85223 & -7.58302 \\
\hline 9 & NCB & 0.02174 & -1.32327 & -0.99117 & 8.43607 & -0.71769 & -7.71838 \\
\hline 10 & ONB & 0.02097 & -1.25095 & -0.94998 & 1.39430 & 5.55629 & -6.95059 \\
\hline 11 & PBB & -0.30382 & -0.10907 & -0.59232 & 1.30503 & 1.10581 & -2.70945 \\
\hline 12 & SJB & -0.01251 & -1.32341 & -0.89678 & 7.56183 & 2.09462 & -9.65646 \\
\hline 13 & SEB & 0.00590 & -1.35652 & -0.95643 & 1.89042 & 6.12957 & -8.01999 \\
\hline 14 & STB & -0.00677 & -1.26479 & -0.89997 & 1.57123 & 4.68853 & -6.25976 \\
\hline 15 & UTB & -0.02118 & -1.34724 & -1.04616 & 0.07182 & 1.48620 & -2.99356 \\
\hline
\end{tabular}

After transformation, the modified ARDL $(2,2)$ model obtained from the original ARDL model is proposed in the following form;

$\beta_{1}, \beta_{2}, \alpha_{1}, \alpha_{2}$ are the coefficients of $\Delta Y_{t}, \Delta^{2} Y_{t}, \Delta X_{t}$ and $\Delta^{2} X_{t}$ respectively.

And the fitted ARDL(2,2) regression model for AB bank is as following:

$$
\begin{gathered}
\hat{Y}_{t}=\hat{\beta}_{0}^{\prime}+\hat{\beta}_{1}^{\prime} Y_{t-1}+\hat{\beta}_{2}^{\prime} Y_{t-2}+\hat{\alpha}_{0}^{\prime} X_{t}+\hat{\alpha}_{1}^{\prime} X_{t-1}+\hat{\alpha}_{2}^{\prime} X_{t-2} \\
=-0.04724-1.36508 Y_{t-1}-1.10402 Y_{t-2}+1.44927 X_{t}+7.76590 X_{t-1}-9.21518 X_{t-2}
\end{gathered}
$$

Where, $Y_{t}$ and $X_{t}$ represent the $\log$ return $\left(\ln \mathrm{r}_{\mathrm{t}}\right)$ and $\log$ daily average( $\left.\ln \mathrm{dav}\right)$ of AB bank at trade date $t$. In the above model the estimated parameters are replaced from the Table 8. Similarly the fitted regression model for 
others companies can be written from this table. From the estimated parameters it is seen that all the regression coefficients of $Y_{t-1}, Y_{t-2}$ and $X_{t-2}$ have the negative effects on $Y_{t}$ and the other coefficients have both positive and negative effect. Moreover, the log daily average $X_{t}$ has more positive effect on $Y_{t}$ for $\mathrm{AL}$ ARAFAH bank, EXIM bank, NCC bank, SHAHJALAL bank.

Now the 1- step ahead forecasted model for the log return of AB bank will be;

$$
\begin{gathered}
\hat{Y}_{t+1}=\hat{\beta}_{0}^{\prime}+\hat{\beta}_{1}^{\prime} Y_{t}+\hat{\beta}_{2}^{\prime} Y_{t-1}+\hat{\alpha}_{0}^{\prime} X_{t+1}+\hat{\alpha}_{1}^{\prime} X_{t}+\hat{\alpha}_{2}^{\prime} X_{t-1} \\
\text { or, } \hat{Y}_{t}(1)=-0.04724-1.36508 Y_{t}-1.10402 Y_{t-1}+1.44927 X_{t+1}+7.76590 X_{t}-9.21518 X_{t-1}
\end{gathered}
$$

And the 1- step ahead forecasted volatility model for AB bank will be;

$$
\hat{\sigma}_{t+1}^{2}=\underset{(0.000)}{0.03729}+\underset{(0.001)}{0.20143} a_{t}^{2}
$$

Where, $\mathrm{X}_{\mathrm{t}+1}$ is the log daily average of an asset at trade date $(\mathrm{t}+1)$, which is not available. So, this value can be replaced by the average of previous traded 30 days log daily averages.

Suppose, to predict the daily log return of AB bank for 28th December, 2015 where the data are available up to 27th December, 2015 the forecasted model will be;

$$
\begin{aligned}
\hat{Y}_{28 t h d e c, 15}= & -0.04724-1.36508 Y_{27 \text { th dec, } 15}-1.10402 Y_{26 \text { th dec, } 15}+1.44927 X_{28 \text { th dec, } 15} \\
& +7.76590 X_{27 \text { th dec, }, 15}-9.21518 X_{26 \text { th dec, }, 15} \\
=-0.04724-1.36508 \times(-0.08)-1.10402 \times(-0.36)+1.44927 \times 3.01 & +7.76590 \times 3.04- \\
9.21518 \times 3.04= & 0.41591
\end{aligned}
$$

And the predicted gross return is 1.13055

With 1-step ahead volatility

$$
\hat{\sigma}_{28 \text { th dec, } 15}^{2}=\underset{(0.000)}{0.03729}+\underset{(0.001)}{0.20143} a_{27 \text { th dec, } 15}^{2}
$$

Similarly, the forecasting for others banks can be done.

\section{Conclusion}

In this study, the daily returns based on the daily total turnover values of 15 renowned banks listed in Chittagong Stock Exchange, Bangladesh have been analyzed. Secondary data are collected for the period 1st January 2009 to 27th December 2015 from the CSE. The summary of the out puts are following as:

i. Monthly average return per day for all banks lies between 1.13 and 2.69. The yearly average gross return per is highest for Dhaka Bank and lowest is for AB Bank.

ii. From histogram it is obvious that the daily log returns for all banks are almost normally distributed.

iii. Monthly average gross return per day for all banks are not seems to be stationary but In both graphical method and statistical method, the daily log returns of all selected companies are stationary in nature.

iv. Variance Inflating Factor is an important tool to check the multicollinearity. The average VIF for all companies are less than 10 , indicate the not severity of multicollinearity and can use these explanatory variables $\Delta \mathrm{Y}_{\mathrm{t}}, \Delta^{2} \mathrm{Y}_{\mathrm{t}}, \Delta \mathrm{X}_{\mathrm{t}}$ and $\Delta^{2} \mathrm{X}_{\mathrm{t}}$ in the model.

v. Generally in time series data, after fitting a mean regression model ARCH effect is tested for building a volatility model. Lagrange multiplier (LM) test is the common method to test the ARCH effect. Significant LM test statistic indicates the situation of having ARCH effect. So, it can be concluded that 
the data getting from all the banks have the conditional heteroscadisticity in the behavior of their residuals. The measures of volatility, Parkinson's extreme value estimator based on intra-day high and low price of an asset is more efficient, Parkinson's extreme value estimator also conferred the conditional heteroscadisticity in the behavior of their residuals.

vi. The dynamic regression models with volatility regression of $\mathrm{ARCH}$ effect for all banks are run and the parameters for corresponding banks are estimated. It is observed that 1st difference of both log return and $\log$ daily average have the significant positive effect on log daily return but the 2 nd difference have the significant opposite effect on the daily log return.

vii. The fitted model cannot be used in forecasting due to its complex form having the difference terms of both dependent variable and independent variable as a explanatory variable. So, the proposed fitted modified ARDL model and volatility model will be described for forecasting which removes the complexity of the previous fitted model.

viii. And the fitted proposed $\operatorname{ARDL}(2,2)$ regression model for $\mathrm{AB}$ bank is as following:

$$
\begin{gathered}
\hat{Y}_{t}=\hat{\beta}_{0}^{\prime}+\hat{\beta}_{1}^{\prime} Y_{t-1}+\hat{\beta}_{2}^{\prime} Y_{t-2}+\hat{\alpha}_{0}^{\prime} X_{t}+\hat{\alpha}_{1}^{\prime} X_{t-1}+\hat{\alpha}_{2}^{\prime} X_{t-2} \\
=-0.04724-1.36508 Y_{t-1}-1.10402 Y_{t-2}+1.44927 X_{t}+7.76590 X_{t-1}-9.21518 X_{t-2}
\end{gathered}
$$

Where, $Y_{t}$ and $X_{t}$ represent the $\log$ return $\left(\ln \mathrm{r}_{\mathrm{t}}\right)$ and $\log$ daily average $(\ln$ dav $)$ of $\mathrm{AB}$ bank at trade date $t$.

Similarly the fitted regression model for all others banks can be written.

ix. $\quad$ Now the 1- step ahead forecasted model for the log return of AB bank will be;

$$
\begin{aligned}
& \hat{Y}_{t+1}=\hat{\beta}_{0}^{\prime}+\hat{\beta}_{1}^{\prime} Y_{t}+\hat{\beta}_{2}^{\prime} Y_{t-1}+\hat{\alpha}_{0}^{\prime} X_{t+1}+\hat{\alpha}_{1}^{\prime} X_{t}+\hat{\alpha}_{2}^{\prime} X_{t-1} \\
& \text { or, } \hat{Y}_{t}(1)=-0.04724-1.36508 Y_{t}-1.10402 Y_{t-1}+1.44927 X_{t+1}+7.76590 X_{t}-9.21518 X_{t-1}
\end{aligned}
$$

And the 1- step ahead forecasted volatility model for AB bank will be;

$$
\hat{\sigma}_{t+1}^{2}=\underset{(0.000)}{0.03729}+\underset{(0.001)}{0.20143 a_{t}^{2}}
$$

Where, $\mathrm{X}_{\mathrm{t}+1}$ is the log daily average of an asset at trade date $(t+1)$, which is not available. So, this value can be replaced by the average of previous traded 30 days log daily averages.

Suppose, to predict the daily log return of AB bank for 28th December, 2015 where the data are available up to 27th December, 2015 the forecasted model will be;

$$
\begin{aligned}
\begin{aligned}
& \hat{Y}_{28 \text { th dec, } 15}=-0.04724-1.36508 Y_{27 \text { th dec, } 15}-1.10402 Y_{26 \text { th dec, } 15}+1.44927 X_{28 \text { th dec, } 15} \\
&+7.76590 X_{27 \text { th dec, } 15}-9.21518 X_{26 \text { th dec, } 15} \\
&=-0.04724-1.36508 \times(-0.08)-1.10402 \times(-0.36)+1.44927 \times 3.01 \\
& \quad 7.76590 \times 3.04-9.21518 \times 3.04
\end{aligned} \\
=0.41591
\end{aligned}
$$

And the predicted gross return is 1.13055 
With 1-step ahead volatility

$$
\hat{\sigma}_{28 t h d e c, 15}^{2}=\underset{(0.000)}{0.03729}+\underset{(0.001)}{0.20143} a_{27 t h d e c, 15}^{2}
$$

Similarly, the forecasting for others bank can be done.

\section{References}

Ainul, I., \& Khaled, M. (2005). Tests of weak-form efficiency of the Dhaka stock exchange. Journal of Business Finance \& Accounting, 32(7-8), 1613-1622. https://doi.org/10.1111/j.0306-686X.2005.00642.x

Ajab Al, F. (2012). A study on the behavior of volatility in Saudi Arabia stock market using symmetric and asymmetric GARCH Models. Journal of Mathematics and Statistics, 8(1), 98-106. https://doi.org/10.3844/jmssp.2012.98.106

Bae, J. C. (2007). Why are stock returns and volatility negatively correlated? Journal of Applied Finance, 14(1), 41-58. https://doi.org/10.1016/j.jempfin.2006.04.005

Baillie, R. T., \& R. P. DeGennaro (1990). Stock Returns and Volatility. Journal of Financial and Quantitative Analysis, 25, 203-215. https://doi.org/10.2307/2330824

Beer, Fransisca M., Yu-Tsui, L., \& Chi-Shun, C. (2006). Stock Returns and Volatility: Evidence from the Chinese Markets. Journal of Emerging Markets, 11(3), 40-49.

Bucevska, V. (2012). An empirical evaluation of GARCH Models in value-at-risk estimation: evidence from the Macedonian stock exchange. Business Systems Research Journal, 4(1), 49-64.

Campbell, J. Y., Lo, A. W., \& MacKinlay, A. C. (1997). The Econometrics of Financial Markets. Princeton University Press, Princeton, NJ.

Chowdhury, S. S. H., Sadique, M. S., \& Rahman, M. A. (2001). Capital market seasonality: The case of Dhaka stock exchange (DSE) returns. South Asian Journal of Management, 8, 1-8.

Dickey, D. A., \& Fuller, W. A. (1979). Distribution of the estimates for autoregressive time series with a unit root. Journal of the American Statistical Association, 74, 427-431.

Dima, A., Haim, S., \& Rami, Y. (2008). Estimating stock market volatility using asymmetric GARCH models. Applied Financial Economics, 18, 1201-1208. https://doi.org/10.1080/09603100701604225

Elsheikh, A. A. (2011). Modeling stock market volatility using GARCH models evidence from Sudan. International Journal of Business and Social Science, 2(23), 114-128.

Engle, R. F., David, M. L., \& Russell, P. R. (1987). Estimating time varying risk premia in the term structure: The ARCH-M model. Econometrica, 55, 391-407. https://doi.org/10.2307/1913242

French, K. R., G. W. Schwert, \& R. E. Stambaugh (1987). Expected Stock Returns and Volatility. Journal of Financial Economics, 19, 3-29. https://doi.org/10.1016/0304-405X(87)90026-2

Guo, Z. Y. (2017). GARCH Models with Fat-tailed Distributions and the Hong Kong Stock Market Returns. International Journal of Business and Management, 12(9), 28-37. https://doi.org/10.5539/ijbm.v12n9p28

Hassan, M. K., \& Chowdhury, S. S. H. (2008). Efficiency of Bangladesh stock market: Evidence from monthly index and individual firm data. Applied Financial Economics, 18(9), 749-758. https://doi.org/10.1080/09603100701320178

Islam, M. (2013). Modeling univariate volatility of modeling univariate volatility of evidence from 4-Asian markets. International Research Journal of Finance and Economics, 163, 110-117.

Kader, A. A., \& Rahman, M. A. (2005). Testing the weak -form efficiency of an emerging market: Evidence from the Dhaka Stock Exchange of Bangladesh. AIUB Journal, 4(2).

Masulis, R. W., \& V. Ng (1995). Overnight and Daytime Stock-return Dynamics on the London Stock Exchange: The Impacts of 'big bang' and the 1987 Stock-market Crash. Journal of Business \& Economic Statistic, 13(4), 365-378. https://doi.org/10.2307/1392383

Md. Ariful, I., Md. Rayhan, I., \& Mahmudul, H. S. (2014). Stock market volatility: Comparison between Dhaka stock exchange and Chittagong stock exchange. International Journal of Economics, Finance and Management Sciences, 2(1), 43-52. https://doi.org/10.11648/j.ijefm.20140201.16 
Mobarek, A., Mollah, S. A., \& Bhuyan, R. (2008). Market efficiency in emerging stock market: Evidence from Bangladesh. Journal of Emerging Market Finance, 7(1), 17-41. https://doi.org/10.1177/097265270700700102

Naik, P. K., \& Padhi, P. (2012). The Impact of Macroeconomic Fundamentals on Stock Prices Revisited: Evidence from Indian Data. Eurasian Journal of Business and Economics, 5(10), 25-44.

Parkinson, M. (1980). The extreme value method for estimating the variance of the rate of return. Journal of Business, 53, 61-65. https://doi.org/10.1086/296071

Suliman, Z. S. A. (2012). Modelling stock market volatility using univariate GARCH models evidence from Sudan and Egypt. International Journal of Economics and Finance, 4(8), 161-176.

Uddin, Md. G. S., \& Khoda, N. M. A. K. (2009). "An empirical examination of random walkhypothesis for Dhakastock exchange: evidence from pharmaceutical sector of Bangladesh. International Research Journal of Finance and Economics, 33, 87-100.

Uddin, Md. G. S., \& Shakila, Y. (2008). Random walk model in the Dhaka stock exchange: An empirical evidenceof daily returns. Journal of Business Administration, IBA, Dhaka University, 35(1 \& 2), 75-86.

\section{Copyrights}

Copyright for this article is retained by the author(s), with first publication rights granted to the journal.

This is an open-access article distributed under the terms and conditions of the Creative Commons Attribution license (http://creativecommons.org/licenses/by/4.0/). 